\title{
A case study of curriculum development: Backward or forward/central design?
}

\author{
Nguyen Thanh Tung ${ }^{1 *}$ \\ ${ }^{1}$ Ho Chi Minh City University of Education, Vietnam \\ *Corresponding author: tungnth@hcmue.edu.vn
}

ARTICLE INFO

DOI: $10.46223 / \mathrm{HCMCOUJS}$ soci.en.10.1.546.2020

Received: June $14^{\text {th }}, 2020$

Revised: June $22^{\text {nd }}, 2020$

Accepted: June $29^{\text {th }}, 2020$

Keywords:

curriculum development, backward design, constructive alignment, objective, syllabus, methodology, evaluation
ABSTRACT

Nowadays universities in Vietnam have begun to update their curricula by adopting a backward design with a focus on students' learning outcomes to replace the old-fashioned forward model. However, to have a constructive alignment is a problem they have to face. This situation has prompted this case study research in May 2020 , intending to examine a curriculum to find out whether it is coherent in terms of its main components - objectives, syllabus, methodology, and evaluation. The findings of the study indicate that for this case, although the curriculum was claimed to be of a backward design with learning outcomes as program objectives, it turned out to follow a forward one with more focus on knowledge transfer than competency development. In particular, as the program learning objectives were still written according to knowledge transmission, it was not constructively aligned with the three main components of syllabus, methodology and evaluation: The syllabi were mainly based on the experience of the experts in the field or syllabus designers, the innovation of the methodology as directed by the university with a shift of focus from the lecturer to learners was still interpreted rigidly and mechanically, and the evaluation of student learning was generally claimed to be criterionreferenced only without any elaboration for each syllabus.

\section{Introduction}

To meet the requirements of the fundamental and comprehensive reform of education and training in the context of Vietnam's international integration based on Resolution 29-NQ/TW in 2013 (Central Executive Committee, 2013), universities have changed from a focus on the transfer of knowledge from the teacher to learners to that on the development of learners' competencies and attributes. As a result, a new model of curriculum development has been adopted recently in response to this demand. However, as this is a new paradigm, confusion and difficulty are unavoidable. For instance, in a study for a Master's thesis in the English language teaching, a candidate claimed to investigate a curriculum with learning outcomes, i.e., a backward design; however, it turned out later that she used the theoretical framework of process design; and finally she prepared a questionnaire with items asking about the respondents' experiences in a forward design, but claimed the responses to be of a backward design. Therefore, to prevent "a new bottle of old wine" (i.e., an old product with new packaging) from occurring, it is necessary to examine a curriculum developed using a backward design to see whether it is main components of syllabus, methodology and evaluation have been constructively aligned with the learning outcomes as 
claimed in the program objectives.

To achieve this aim, the study poses the following two research questions:

1. Is the design of the curriculum under investigation backward?

2. To what extent are the main components of the curriculum, i.e., syllabus, methodology, and evaluation, constructively aligned to achieve the program learning outcomes?

\section{Conceptual framework}

\section{Approaches to curriculum development in language teaching}

The word "curriculum" is used to cover all the components which contribute to the instructing and learning circumstance; in developing a curriculum, coherence should be achieved to have a coherent curriculum as these components are interdependent (Johnson, 1989, p. 11). They are normally defined as objectives, syllabus, methodology, and evaluation (White, 1988, p. 5).

In the model of curriculum development by Taba and Tyler, a distinction is made between goals, aims and objectives. Goals are very general and broad, aims are more specific, and longterm goals and objectives are the short-to-medium-term goals (Taba, 1962, as cited in White, 1988, p. 27).

According to Richards (2013), language programs can be approached in three different ways, depending on whether the developer pays more attention to any of the following components of the curriculum: input (syllabus), process (methodology), or output (evaluation/learning outcomes). Therefore, the language curriculum can focus on input, process, or output with three different designs accordingly: forward, central and backward. For the forward design, the content of instruction is settled prior choices about methodology and output are resolved; with the central design, educational program development begins with the determination of teaching activities, techniques and methods rather than with the elaboration of detailed language contents or specification of learning results; and finally, the backward design begins with a cautious proclamation of the desired results or outcomes, and appropriate content and teaching activities are derived from the results of learning (ibid.).

\section{Objectives}

In language pedagogy, various ways of expressing program objectives are normally utilized as "variations in practice reflecting different perceptions of the nature of second or foreign language proficiency" (Richards, 1985, p. 15). In particular, this researcher proposes stating objectives in four different ways which are behavioral objectives, process-related objectives, content-related objectives, and proficiency-related objectives. Under scrutiny and with the three different designs in curriculum development that are forward, central and backward as presented above, these ways can be reordered as follows to correspond to this order: content-related, processrelated, and behavioral objectives, respectively. The last one is actually for the design which focuses on the learning outcomes, or a "means-ends" curriculum model by Taba and Tyler (as cited in White, 1988, p. 26).

In an attempt to translate objectives into behavioral terms using the cognitive domain, educators use the old version of the Bloom's taxonomy with six categories of knowledge, comprehension, application, analysis, synthesis, and evaluation (White, 1988, p. 28). The revised version employs verbs instead of nouns with minor changes: remember, understand, apply, analyze, evaluate, and create. Drawing on the classical prescription for behavioral objectives, 
Steiner (1975) (as cited in White, 1988, pp. 28-29) proposes writing the objectives which focus on performance with a specification of criteria concerning: (1) what students will do, (2) under what conditions, (3) within what time, and (4) to what level of mastery. Therefore, "if the learners' behavior matches the specification, they have achieved mastery of the objectives concerned" (While, 1988, p. 29).

\section{Syllabus}

There are various types of syllabus depending on the design selected. Some curriculum models are primarily content-oriented, and the linguistic/language syllabus is fundamental in the development of language teaching practices; an alternative is a process-based syllabus where the methodology is developed directly from an appropriate instructional theory which typically contains an account of underlying processes in foreign language acquisition with a specification of relevant teaching and learning activities; finally, a curriculum which specifies tasks rather than linguistic content or procedures/activities is referred to as employing a task-based syllabus with pre-specifying learning outcomes in the form of objectives (Richards, 1985, pp. 20-26). Later in 2013, this researcher made a distinction between two versions of tasks depending on whether they are meaningful or communicative and explicitly stated that they are used in central and backward design respectively (Richards, 2013). Care must be taken as earlier in 1988, Nunan only had made a distinction between product-oriented syllabuses and process-oriented syllabuses. For the former, he included both grammatical and functional-notional syllabuses. Therefore, the product of learning according to this researcher refers to the forward design according to Richards (2013).

In the same vein, Dubin and Olshtain (1986) posit that for different curriculum goals, i.e., views on education or approaches to curriculum development, course designers ask different questions with the syllabus. These researchers articulate that if a specific hypothesis of language has been utilized as the establishment of the curriculum, the course designers are apt to pose key inquiries about language contents, such as the elements of language content to be chosen for incorporation into the syllabus, the order/sequence of these elements to be introduced in the syllabus, and the criteria for this order of the elements in the syllabus; on the other hand, in the event that language learning or a specific way of thinking about education has had a solid impact, then course organizers would pose inquiries about the process dimension, for example, the procedure for introducing language to facilitate the acquisition process, the roles of the instructor and learners in the learning process, and the procedure for the materials to contribute to the process of language learning; however, where explicit accomplishments or learning results have assumed the prevailing role in the educational plan, course planners will ask product/result questions about knowledge the students are expected to achieve by the end of the course, specific language skills they need in their expert lives, and the techniques of assessment/examination to assess course outcomes (ibid., p. 42).

\section{Methodology}

Different designs required alternative methodologies to tailor the change in the focus of curriculum development: content/language, activities/tasks, or learning results. However, a brief history of the teaching methods is needed first by examining major trends in the twentieth-century language teaching methodologies. Under scrutiny, six major tendencies can be isolated as follows: GTM in the $17^{\text {th }}, 18^{\text {th }}$ and $19^{\text {th }}$ century, Direct Method (DM) at the turn of the $20^{\text {th }}$ century, ALM during the 50s-60s, CLT during 70s-80s, and 90s with two tendencies of TBLT 1 and TBLT $_{2}$ (Richards \& Rodgers, 2001). As far as language teaching methodologies are concerned, methods can be grouped into three depending on whether they focus on language, learning or learner. Under this classification, they can belong to language-centered methods, learning-centered methods and 
learner-centered methods (Kumaravadivelu, 2008). Based on this classification, the first four trends above belong to group 1, trend 5 fits in group 2, and the last is reserved for group 3.

In the same vein, but in the association with curriculum development, some methods are more suitable for one design than another. Specifically, according to Richards (2013), the following methods belong to a forward design with the focus on content/language/syllabus: the audiolingual method (ALM), the audiovisual method, the structural situational method, and even the more recent examples of communicative language teaching (CLT) and content-based teaching/instruction (CoBI)/content and language integrated learning (CLIL); the following methods have been cited as examples of central design methods focusing on the process of learning: the natural approach, the silent way, counseling learning, task-based language teaching (TBLT) (Version 1), and Dogme; and backward design methods include TBLT (Version 2), competency-based instruction (CpBI), and the use of standards and the Common European Framework of Reference (CEFR).

\section{Evaluation}

Green (2014) traces back the development of testing and assessment over time and proposes 6 phrases or tendencies in language assessment. The following sequence was adapted in this paper a little to be consistent with the stages of development in the teaching methods presented above: (1) pre-scientific/traditional, (2) psycholinguistic-socio-linguistic, (3) psychometric-structuralist, (4) communicative, (5) assessment for learning, and (6) formative assessment. According to this author, four different concerns for the last four main stages of development are reliability, the validity of the content, the process of learning, and the products of learning, respectively (ibid. $p$. 174). He also makes a distinction between assessment for learning and formative assessment for the last two phases accordingly. He also cited Poehner (2008) as distinguishing these two types as interactionist and interventionist, respectively (Green, 2014, p. 207). With a focus on products of learning, testing should be criterion-referenced (White, 1988, p. 29).

\section{Research methodology}

As the aim of the study is to examine a language curriculum at a university only to shed light on its development with the complexity of such factors of views, objectives, syllabus, methodology, and evaluation, a case study seems to be more appropriate for this kind of research. As Yin (2003) articulates, "the distinctive need for case studies arises out of the desire to understand complex social phenomenon" (p. 2). Specifically, Nunan (1992) also posits that a case study is suitable for program evaluation as "the general purpose of the evaluation was to provide information to the education authorities" (p. 201) who had looked for an innovative curriculum designed to improve the learning of students in this less "advantaged" area of the country. Therefore, this design is believed to be able to address the complexity of the factors involved in the curriculum development of a particular educational institution.

The English language curriculum of the Faculty of Foreign Languages of a university in a province on the southeast coast in Vietnam was examined in May, 2020. It consists of 697 pages with the two parts of A. General information and B. Program objectives and learning outcomes. The main part of $\mathrm{B}$, in its turn, is composed of 12 sections: 1. Program objectives, 2. Program learning outcomes, 3 . The total volume of knowledge, 4. Prospective students, 5. Training process and graduation conditions, 6. Evaluation of student learning, 7. Program contents, 8. Teaching plan, 9. Guide to program implementation, 10. Relationship between program objectives and learning outcomes, 11. Relationship between course objectives and program learning outcomes, and 12. Syllabi. 
According to Nunan (1992), to evaluate a program, one has to consider points of focus. This author also suggests some key questions in program evaluation in terms of needs analysis (i.e., objectives), content (i.e., syllabus), methodology, and assessment and evaluation (ibid., p. 191). As a matter of fact, these suggestions are the main components of curriculum development as presented in the theory part of this paper. Therefore, the conceptual framework in the theory part above is used for program evaluation. Especially, it was investigated in terms of objectives, syllabus, methodology, and evaluation to find out whether it followed the backward design as claimed and what evidence of this claim it gave in its components.

The participating institution is only described above as a way to protect it from any harm caused for ethical consideration in research because it is a basic premise of ethical research (McDonough \& McDonough, 1997, pp. 132-133).

\section{Data analysis and discussion of findings}

\subsection{Data analysis}

\section{Objectives}

The program objectives in the current curriculum are split into general and specific objectives. Specific objectives are displayed in five sections of knowledge, skills (hard and soft), attitudes (sense of responsibility and professional ethics), career opportunities after graduation, and the chance to go to higher education. The first three subsections are written according to program objectives (POs). In addition, there are program learning outcomes (LOs) which are written according to three subsections of knowledge (8 LOs from 1 to 8), skills hard (6 LOs from 9 to 14 ) and soft (5 LOs from 15 to 19)) and competencies in autonomy and responsibility (5 LOs from 20 to 24). All these three subsections are written according to LOs.

Specifically, for the first subsection of knowledge, nearly all of the eight LOs, from 1 to 8 , as shown in nearly all the syllabi, are about knowledge with the use of such words as "knowledge about..." or equivalents. There are even cases where the verb "provide" is used before the word knowledge. Even in the second subsection of skills in program learning outcomes, knowledge is also referred to with the use of such verbs as "understand" and "recognize".

\section{Syllabus}

For a great majority of the syllabi in this curriculum, the teaching and learning contents are based not really on the program learning outcomes as claimed, but actually on the available chapters of the books used as the coursebooks. These chapters are then transferred into the syllabi and superficially claimed to be the contents selected to serve the program learning results.

Section 4 Contents of the course and the part about contents of the course in Section 8 Teaching plan in nearly all the syllabi are almost the same and lengthy with too many details. An example is a syllabus of Speaking 3 with up to 13 pages.

It can be easily seen that the content is based on a Course Expected Learning Outcomes (CELOs) and these CELOs are aligned to program Learning Objectives (i.e., LOs). However, there are too many CELOs for nearly all the syllabi, especially those of Speaking (Speaking 2: 53, Speaking 3: 48, Speaking 1: 40), Linguistics (Semantics: 32, Phonetics: 30, Syntax: 30, Morphology: 20, An introduction to linguistics: 19), Pronunciation (Pronunciation 1: 30, Pronunciation 2: 20), Grammar (Grammar 1: 21, Grammar 2: 23, Grammar 3: 26), Chinese (Chinese $1 \& 2: 20$ for each). More importantly, the contents of all the syllabi are based on CELOs, but not directly on LOs. 


\section{Methodology}

The teaching and learning methods for all the courses in the curriculum are summarized and presented in the following table.

\section{Table 1}

Teaching and learning methods in courses

\begin{tabular}{|c|l|l|c|}
\hline No & Teacher \& learner activities & \multicolumn{1}{|c|}{ Courses } & Total \\
\hline 1 & $\begin{array}{l}1 \text { teacher activity and 6 learner } \\
\text { activities }\end{array}$ & $\begin{array}{l}\text { Listening 1,2,3 \& 4; Reading 1,2 \& 3; Writing 1, } \\
2 \text { \& 3; Advanced English }\end{array}$ & 11 \\
\hline 2 & $\begin{array}{l}4 \text { teacher activities \& } \\
\text { corresponding } \\
\text { activities }\end{array}$ & $\begin{array}{l}\text { Grammar 1, 2 \& 3; Speaking 1, 2, 3 \& 4; An } \\
\text { introduction to linguistics; Applied Vietnamese } \\
\text { language; English for offices; British literature; } \\
\text { Studies of English speaking countries; Methodology } \\
\text { for teaching English; English teaching practices }\end{array}$ & 14 \\
\hline 3 & $\begin{array}{l}8 \text { teacher activities \& 4 learner } \\
\text { activities }\end{array}$ & $\begin{array}{l}\text { Pronunciation 1 \& 2; Phonetics; Chinese 1 \& 2; } \\
\text { Morphology; Syntax }\end{array}$ & 7 \\
\hline 4 & $\begin{array}{l}\text { Mainly teacher presentation in } \\
\text { form of active interaction }\end{array}$ & $\begin{array}{l}\text { Physical education 1 \& 2; Marxist-Leninist } \\
\text { philosophy; Political economics of Marxism and } \\
\text { Leninism; Scientific socialism; Ho Chi Minh } \\
\text { ideology; History of Vietnam Communist Party }\end{array}$ & 7 \\
\hline 5 & $\begin{array}{l}\text { Teacher presentation with a } \\
\text { focus on language }\end{array}$ & $\begin{array}{l}\text { English for business 1 \& 2; Translation theory and } \\
\text { practice; Interpretation practice }\end{array}$ & 4 \\
\hline 6 & $\begin{array}{l}\text { Various presentation } \\
\text { English for tourism 1 \& 2; Basic informatics; } \\
\text { Internship/Practicum }\end{array}$ & 4 \\
\hline
\end{tabular}

Source: The researcher's data analysis

As seen from the table above, for group 1 there are 11 syllabi with only one teacher activity which is "explanation, knowledge presentation". Nevertheless, there are three activities for students as follows: group discussion and exercises, individual writing practice, consolidation of the previous knowledge through relevant questions. In group 2, there are 14 syllabi with four teacher activities of explanation and knowledge presentation, activity organization, skill instruction, class management, and four corresponding student activities of note-taking of knowledge, activity participation, individual/group work, and participation. As for group 3, there are seven syllabi with eight teacher activities which are "Lesson introduction, presentation, explanation, task/exercise/activity assignment, practice instruction, game organization, evaluation, and summary, and four student activities of listening, note-taking, practicing, doing exercises, participating in activities. Seven syllabi of group 4 mainly use the teacher activity of "presentation in the form active interaction (by using questions to elicit answers)" and the corresponding student activity of "Listening, receiving and comprehending the transferred knowledge". Group 5 consists of the teacher activities of "explanation and knowledge presentation, explanation of specialized terms, a supply of vocabulary and sentence patterns usually used in class, and consolidation of the lesson via relevant questions" and the student activities of "group discussion and speaking practice, (listening, speaking practice and exercise doing)". The last group is composed of each syllabus with its own presentation. Especially, the syllabus Basic informatics has the teacher activity which 
is "presentation in the form of active interaction (by using questions to elicit answers)"; however, after a few sessions, there is a student activity which comprises "presenting a topic, guiding the discussion, giving criteria for assessing the quality of discussion” with specific steps.

\section{Evaluation}

There are two sections in nearly all the syllabi for the evaluation of student learning: Section 6 Evaluation of student learning the last component of which is about the final exam and Section 10 End-of-term exam.

Generally speaking, there are two distinct ways to evaluate student learning, depending on whether the components are divided up into three or five. The details for these two groups are presented below:

3 parts: Grammar 1, 2 \& 3; Speaking 1, 2, 3 \& 4; English for offices; Methodology for teaching English; English teaching practices; Physical education $1 \& 2$ (Total: 12 courses).

5 parts: The remaining courses (except Internship/Practicum).

The first group of courses split up into 3 components for evaluation consists of attendance $(10 \%)$, process $(30 \%)$ and final exam $(60 \%)$, while the other is divided up into the five parts of attendance $(10 \%)$, exercises $(10 \%)$, skill-practice $(10 \%)$, process $(10 \%)$, and final exam $(60 \%)$. Therefore, for the second group, formative assessment, i.e., process assessment in the syllabi of this curriculum, only accounts for $10 \%$ of the total score.

What is more important is that in both the process assessment and final exam, it is clearly stated that for these two types of assessment, student learning is "assessed through criteria (which are made public, i.e., transparent). This is followed by a general statement for nearly all the courses that learners will be informed of the central, in-depth, and extensive knowledge for both formative and summative assessment.

\section{Table 2}

The relationship between objectives for attendance and courses

\begin{tabular}{|c|l|l|c|}
\hline No & \multicolumn{1}{|c|}{ Objectives } & \multicolumn{1}{|c|}{ Course } & Total \\
\hline 1 & CO1 & $\begin{array}{l}\text { Pronunciation 1 \& 2; Listening 1, 2 \& 3; An introduction to linguistics; } \\
\text { Writing 1, 2 \& 3; Reading 2 \& 3; British literature, Morphology, Syntax, } \\
\text { English for business 1 \& 2; Semantics; Translation theory and practice; } \\
\text { Interpretation practice; Advanced English }\end{array}$ & 20 \\
\hline 2 & CO1, CO2 & $\begin{array}{l}\text { Grammar 1, 2 \& 3; Speaking 1, 2, 3, \& 4; Reading 1, Applied } \\
\text { Vietnamese language, English for offices, Studies of English speaking } \\
\text { countries, Listening 4, English for tourism 2; Methodology for teaching } \\
\text { English; English teaching practices; Research methodology }\end{array}$ & 16 \\
\hline 3 & Nil & $\begin{array}{l}\text { Physical education 1 \& 2, History of Vietnam Communist Party } \\
\text { Leninist-Leninist philosophy; Political economics of Marxism and }\end{array}$ & 3 \\
\hline 4 & CO1, CO3 & Chinese 1 \& 2 & 3 \\
\hline 5 & CO2 & Career orientation & 1 \\
\hline 6 & CO1 to CO4 & Phonetics & 1 \\
\hline 7 & CO6, CO7, CO9 & 1 \\
\hline 8 & CO1, CO3, CO6 & English for business 1 & 1 \\
\hline 9 & CO1 to CO7 & Basic informatics \\
\hline
\end{tabular}




\begin{tabular}{|c|l|lc|c|}
\hline No & \multicolumn{1}{|c|}{ Objectives } & \multicolumn{1}{|c|}{ Course } & Total \\
\hline 10 & $\mathrm{CO} 2, \mathrm{CO} 3$ & Scientific socialism & 1 \\
\hline 11 & $\mathrm{CO} 1, \mathrm{CO} 2$ & Internship/ Practicum (not 10\%, but 50\%) & 1 \\
\hline & & & Overall total & $\mathbf{5 0}$ \\
\hline
\end{tabular}

Source: The researcher's data analysis

As can be seen from the table above, 50 courses, except for Military and defense education, include checking attendance as a part of the ongoing assessment which accounts for $10 \%$ of the total score. However, the evaluation of the courses is aligned with various course objectives (COs) in 11 groups. The two groups with more courses are the first two. The first with most courses of up to 20 is aligned with only one course objective of $\mathrm{CO}_{1}$, while the second most with 16 is claimed to assess the two of $\mathrm{CO}_{1}$ and $\mathrm{CO}_{2}$. The next two groups have three courses for each with the first one of no course objectives at all and the other of two: $\mathrm{CO}_{1}$ and $\mathrm{CO}_{3}$. The two courses of Chinese 1 and 2 include only $\mathrm{CO}_{2}$. The rest of the groups from 6 to 11 have only one course with various combinations of COs. Why are the courses claimed to achieve various COs with the same component of attendance only? Especially, the course "Basic informatics" helps to achieve up to seven COs for the component with a weight of only $10 \%$ of the total score.

\subsection{Discussion of findings}

\section{Approach to curriculum development}

The curriculum is claimed to adopt a backward design because it starts with the program learning outcomes (LOs). However, these outcomes are written based on knowledge and skills in addition to the competencies of autonomy and responsibility. Also, there are specific objectives written with knowledge, skills and attitudes. Therefore, there is confusion between a backward and forward design: although it is claimed to be of a backward design, it turns out to be a forward one. Further elaboration on this claim can be made in the following four sections of objectives, syllabus, methodology, and evaluation.

\section{Objectives}

As presented in the data analysis, this curriculum includes both specific objectives (POs) and program learning outcomes (LOs). In particular, specific objectives are written according to knowledge, skills and attitudes. Therefore, one might wonder why the curriculum developers included both program (specific) objectives (POs) and program learning outcomes (LOs), especially when the latter are also written according to knowledge and skills for the first two albeit competency for the last one. This occurs, perhaps, due to the confusion between a content-based approach and a competency-based one to curriculum development in developing the current curriculum. Specifically, the former specifies (specific) objectives based on knowledge, skill and attitude, while the latter concentrates on the development of learners' competencies (general and professional) and attributes (MOET, 2018). Thus the part of learning outcomes written according to knowledge and skills does not follow a backward design. As clarified in the theory part, there are three words with similar meanings, but they cannot be used interchangeably: goals, aims and objectives. (Specific) objectives are actually learning outcomes if the design chosen is backward. That is why, for instance, course learning outcomes follow right after course aims in the syllabi of the University of Bedfordshire in the United Kingdom (University of Bedfordshire, n.d.).

\section{Syllabus}

It is very difficult, or almost impossible, to evaluate the contents, or, to put it another way, 
syllabi, which are selected to serve the program learning outcomes as (1) the program learning outcomes (LOs) are not written satisfactorily (with a focus on knowledge and skills, but not competencies), (2) there are many course objectives (COs), and (3) there are too many courses expected learning outcomes (CELOs).

Much of the content in the syllabi is not the core one as guided by the school. For instance, in the program learning outcomes (LOs), it is stated as follows for teaching: teaching.

Knowledge: LO2 Having a general knowledge and professional qualification essential for

Skill: LO10 Applying theoretical and practical knowledge of the field into different contexts.

Earlier, in the general aims of the curriculum, the following is articulated: "having the necessary knowledge and skills to work in the specialized fields that require proficiency in English". Nevertheless, there is only one course for teaching methodology with three credits in the whole curriculum. In addition to the teaching methods for language areas and language skills, the following contents can also be found: "knowing learners' characteristics, having classroom management skills", knowing "strategies ... of leaners", "grasp the theories related to how to use the curriculum...test and evaluate learners". That is not to mention the inclusion of language description. It is clear that the content was selected not according to the program learning outcomes (LOs), but it was only based on the contents available in a certain book prescribed as the textbook of the course. With the example taken, one can easily confirm this claim by comparing the details with the contents of the coursebook by Harmer (2007).

\section{Methodology}

Generally speaking, there is an attempt and effort to innovate teaching and learning methods as directed by the university to accommodate the change in curriculum design from forward to backward. Nevertheless, the focus on knowledge transfer is still prominent whereas the development of learners' competencies to meet the program learning outcomes has not been paid much attention to. The interpretation of the direction for innovating the teaching and learning method is still quite rigid and mechanical.

\section{Evaluation}

Learning results are assessed according to the course objectives, i.e., COs. However, the relationship has not been clarified between COs and program objectives or learning outcomes, which are abbreviated as LOs in the curriculum of this university. More importantly, COs cannot be a valid, reliable and consistent measure for all the syllabi in the curriculum.

A shift from a content-based approach to curriculum development to a learner- or learningcentered one also means that evaluation is to be constructively aligned to accommodate this change in the view on education. It is a positive signal that criterion-referenced evaluation is required by this educational institution for both formative and summative assessment as clearly articulated in nearly all the syllabi. However, specific criteria for each course are not presented, especially in relation to the program learning outcomes.

\section{Conclusions and recommendations}

The discussion of the findings after examining the curriculum of this educational establishment can help draw some main conclusions as follows:

1. Although the developers of the curriculum claimed it to be of a backward design with 
the focus on students' learning outcomes, it turned out to be mainly of a conventional forward design with content-based orientation.

2. As the objectives of the curriculum were constructed in terms of knowledge, skills, and competencies of autonomy and responsibility, the three main components of syllabus, methodology and evaluation lack constructive alignment, especially with the first two of knowledge and skills.

Based on the findings of this study, the following recommendations for the curriculum improvement can be made:

- Firstly, as (specific) objectives can be written in at least three different ways depending on whether the chosen design is forward, central or backward, it is necessary to use behavioral or performance objectives for the current curriculum with a focus on the learning outcomes, i.e. the competencies that learners need to achieve after their graduation: What will learners be able to do?

- Secondly, accordingly, the syllabus must be based strictly on the learning outcomes, i.e., what learners need to know, instead of using all the contents in a particular book as the textbook of the course.

- Thirdly, as the current methodology is still formed-focused with the teacher presentation of knowledge as the main activity in class, there should be a shift to learner-/learning-centered methods with more time reserved for students' self-study, material reading, discussion, exercises, and practice as directed by the university, preferably with an introduction of task-based language teaching/learning.

- Finally, evaluation with a backward design in curriculum development requires a different system in assessing learners' learning results. This innovation is reflected in the syllabi regarding the criteria for both formative and summative assessments. However, as only general terms are mentioned, details of the two types of assessment should be further elaborated on, especially with the inclusion of rubrics to assess learners' performance.

\section{References}

Central Executive Committee. (2013). Nghị quyết số 29-NQ/TW Nghị Quyết về đổi mói căn bản, toàn diện giáo duc và đào tạo, đáp úng yêu cầu công nghiệp hóa, hiện đại hóa trong điều kiện kinh tế thị truờng định huớng xã hội chủ nghĩa và hội nhập quốc tế [Resolution 29$N Q / T W$ on fundamental and comprehensive innovation of education and training to meet the requirements of industrialization and modernization in socialist-oriented market economy]. Retrieved April 5, 2020, from https://thuvienphapluat.vn/van-ban/thuongmai/Nghi-quyet-29-NQ-TW-nam-2013-doi-moi-can-ban-toan-dien-giao-duc-dao-tao-hoinhap-quoc-te-212441.aspx

Dubin, F. D., \& Olshtain, E. (1986). Course design: Developing programs and materials for language learning. Cambridge, UK: Cambridge University Press.

Green, A. (2014). Exploring language assessment and testing: Language in action. London, UK: Routledge.

Harmer, J. (2007). How to teach English. Harlow, UK: Longman.

Johnson, R. K. (1989). The second language curriculum. Cambridge, UK: Cambridge University Press. 
Kumaravadivelu, B. (2008). Understanding language teaching: From method to postmethod. Mahwah, NJ: Lawrence Erlbaum Associates.

McDonough, J., \& McDonough, S. (1997). Research methods for English language teachers. London, UK: Arnold.

Ministry of Education and Training (MOET). (2018). Tài liệu hướng dẫn dạy học theo chuơng trình giáo dục phổ thông mới: Môn tiếng Anh-Ngoại ngũu 1 (Dành cho giáo viên và cán bộ quản lí giáo dục) (A guide to teaching the new curriculum: English - Foreign language 1 (For teachers and educational managers)]. Hanoi, Vietnam.

Nunan, D. (1988). Syllabus design. Oxford, UK: Oxford University Press.

Nunan, D. (1992). Research methods in language learning. Cambridge, UK: Cambridge University Press.

Richards, J. C. (1985). Language curriculum development. Retrieved April 6, 2020, from https://scholarspace.manoa.hawaii.edu/bitstream/10125/38633/1/Richards\%20(1985)_WP4(1).pdf

Richards, J. C. (2013). Curriculum approaches in language teaching: Forward, central and backward design. RELC Journal, 44(1), 5-33. doi:10.1177/0033688212473293

Richards, J. C., \& Rodgers, T. S. (2001). Approaches and methods in language teaching (2nd ed.). Cambridge, UK: Cambridge University Press.

University of Bedfordshire. (n.d.). Syllabus of English syntax. LNG022-3, University of Bedfordshire, Bedfordshire, U.K.

White, R. V. (1988). The ELT curriculum: Design, innovation and management. Oxford, UK: Basil Blackwell.

Yin, R. K. (2003). Case study research: Design and methods (3rd ed.). Thousand Oaks, CA: Sage. 